\title{
General trends in world biogeographic literature: A preliminary bibliometric analysis
}

\author{
Juan J. Morrone ${ }^{1}$ \& José C. Guerrero²
}

'Museo de Zoología "Alfonso L. Herrera", Departamento de Biología Evolutiva, Facultad de Ciencias, Universidad Nacional Autónoma de México
(UNAM), Apdo. postal 70-399, 04510 Mexico, D.F., Mexico. jjm@hp.fciencias.unam.mx.
${ }^{2}$ Departamento de Biología Animal, Facultad de Ciencias, Universidad de Málaga (UMA), 29071 Málaga, Spain. jcguerrero@uma.es.

\begin{abstract}
General trends in world biogeographic literature: A preliminary bibliometric analysis. Records with the search string biogeograph* were collected from the Science Citation Index (SCI). A total of 3456 records were downloaded for the 1945-2006 period from titles of articles and reviews, and 10,543 records were downloaded for 1991-2006, taking into consideration also abstracts and keywords. Temporal trends of publications, geographical and institutional distribution of the research output, authorship, and core journals were evaluated. There were as many as 122 countries carrying out biogeographic research; in the most recent period, USA is the top producing country, followed by the United Kingdom, Australia, France, Germany, Spain, and Canada. There were 17,493 authors contributing to the field. During 1991-2006 there were 4098 organizations with authors involved in biogeographic research; institutions with higher number of papers are the Natural History Museum (United Kingdom), the University of California, Berkeley (USA), the Museum National d'Histoire Naturelle (France), the Universidad Nacional Autónoma de México (Mexico), the American Museum of Natural History (USA) and the Russian Academy of Sciences (Russia). Research articles are spread over a variety of journals, with the Journal of Biogeography, Molecular Phylogenetics and Evolution, Molecular Ecology, and Biological Journal of the Linnean Society being the core journals. From 28,759 keywords retrieved those with the highest frequency were evolution, phylogeny, diversity, mitochondrial DNA, pattern(s), systematics, and population(s). We conclude that publications on biogeography have increased substantially during the last years, especially since 1998. The preferred journal for biogeographic papers is the Journal of Biogeography. Most frequent keywords seem to indicate that biogeography fits well within both evolutionary biology and ecology, with molecular biology and phylogenetics being important factors that drive their current development.
\end{abstract}

KEYWORDS. Biogeography; publications; journals; scientometrics; Science Citation Index.

RESUMEN. Tendencias generales en la literatura biogeografica mundial: un análisis bibliométrico preliminar. Se recolectaron registros con la palabra biogeograph* a partir del Science Citation Index (SCI). Se obtuvo un total de 3456 registros para el periodo 1945-2006, a partir de títulos de artículos y revisiones; y 10,543 registros para 1991-2006, tomando en cuenta también resúmenes y palabras clave. Se evaluaron las tendencias temporales y geográficas de las publicaciones, además de la distribución institucional de la investigación en el área, autoría y revistas principales. Durante 1945-2006 se publicaron 3456 artículos de biogeografía; cuando la búsqueda para 1991-2006 se expandió para buscar el tema en palabras claves y resúmenes, se recuperaron 10,543 registros. Hubo 122 países desarrollando investigación en biogeografía; en el periodo más reciente, los Estados Unidos de América fueron el país principal, seguidos del Reino Unido, Australia, Francia, Alemania, España y Canadá. 17,493 autores contribuyeron a la biogeografía. Durante 1991-2006 hubo 4098 instituciones con autores desarrollando investigación en el área; las que poseen un número mayor de artículos fueron el Natural History Museum (Reino Unido), la University of California, Berkeley (Estados Unidos de América), el Museum National d'Histoire Naturelle (Francia), la Universidad Nacional Autónoma de México (México), el American Museum of Natural History (Estados Unidos de América) y la Academia Rusa de Ciencias (Rusia). Los artículos de investigación se hayan repartidos en una variedad de revistas, siendo las principales el Journal of Biogeography, Molecular Phylogenetics and Evolution, Molecular Ecology y Biological Journal of the Linnean Society. A partir de 28,759 palabras claves, aquellas con mayor frecuencia fueron evolución, filogenia, diversidad, DNA mitocondrial, patrón (patrones), sistemática y población(es). Concluimos que las publicaciones en biogeografía se han incrementado sustancialmente durante los últimos años, en especial a partir de 1998. La revista preferida para artículos biogeográficos es el Journal of Biogeography. Las palabras claves más frecuentes indican que la biogeografía cabe adecuadamente tanto en la biología evolutiva como en la ecología, siendo la biología molecular y la sistemática filogenética los factores que conducen su desarrollo actual.

PALABRAS CLAVE. Biogeografía; bibliometría; publicaciones; revistas; cientimetría; Science Citation Index.

Scientific publications represent a quantitative measure for the basic research activity in a given field. Bibliometric studies have been published in recent years focusing on the performance of particular areas, with varied temporal and geographical foci (e.g., Garg \& Pahdi 2002; Zhu et al. 2004; Ferner \& Aronson 2005; Zorzetto et al. 2006). Two recent studies (Riddle \& Haffner 2004; Posadas \& Donato 2007) have given us some insights into the evolution and dynamics of biogeography. We think that a worldwide analysis focused on biogeographical articles published in scientific journals may help elucidate how the field is structured.

We analyze the development of world production and authorship on biogeography, in order to assess quantitatively several features: temporal trends of publications, geographical 


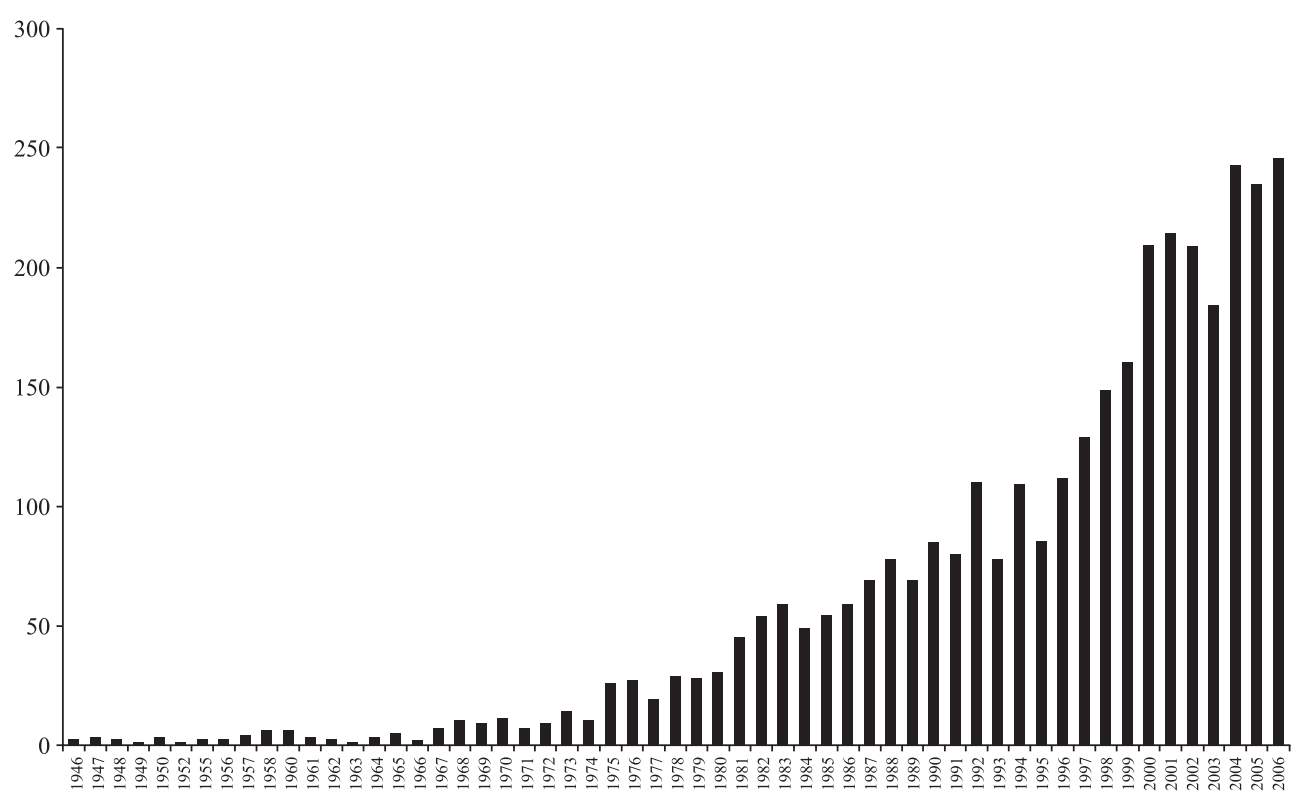

Fig. 1. Number of publications (1946-2006) with biogeograph* in their titles.

and institutional distribution of research output, authorship, and core journals.

\section{METHODS}

Data for the analysis were collected from the Science Citation Index (SCI), a comprehensive data base covering scientific journals, published by Thomson Scientific, Philadelphia, USA. We downloaded two data sets, both restricting our search to articles and reviews, and omitting letters, book reviews, and other minor contributions. The first one consisted of 3456 records from 1945-2006 using the search string biogeograph* in their titles, which was used to estimate the general trend in the annual growth of publications. The second data set, consisting of 10,543 records, was compiled for 1991-2006, period for which keywords and abstracts are also available for the articles contained in SCI. It was used to analyse the geographical and institutional distribution of research output, authorship, and journals during the most recent period. In addition to Science Citation Index, we used software Endnote (Thomson ISI ResearchSoft 1998-2003) for information extraction and processing.

\section{RESULTS}

Temporal trends of publications on biogeography. During 1945-2006 a total of 3456 publications on biogeography was published (Fig. 1), representing an average of 56 publications per year. The growth seems relatively smooth, however, more than half $(53.50 \%)$ of these publications has been published during the last nine years (1998-2006), with the highest number $(246,7.1181 \%)$ in 2006 . When the search for the 1991-2006 allowed to look for the subject additionally in keywords and abstracts, a total of 10,543 of records was retrieved, which show a clearer trend to increase in the last years (Fig. 2). Considering that the complete data base for 1945-2006 includes $37,739,815$ records, 3456 represents a $0.009 \%$ of publications in biogeography, whereas for the second search (1991-2006), for the $18,500,729$ records available, 10,453 represents a $0.056 \%$ of biogeographic articles.

Geographical distribution of research output. During 19452006 there have been as many as 122 countries carrying out biogeographic research. In the most recent period (Table I), USA is the top producing country, followed by the United Kingdom, Australia, France, Germany, Spain, and Canada. Anglo-speaking countries are the three first ones, although

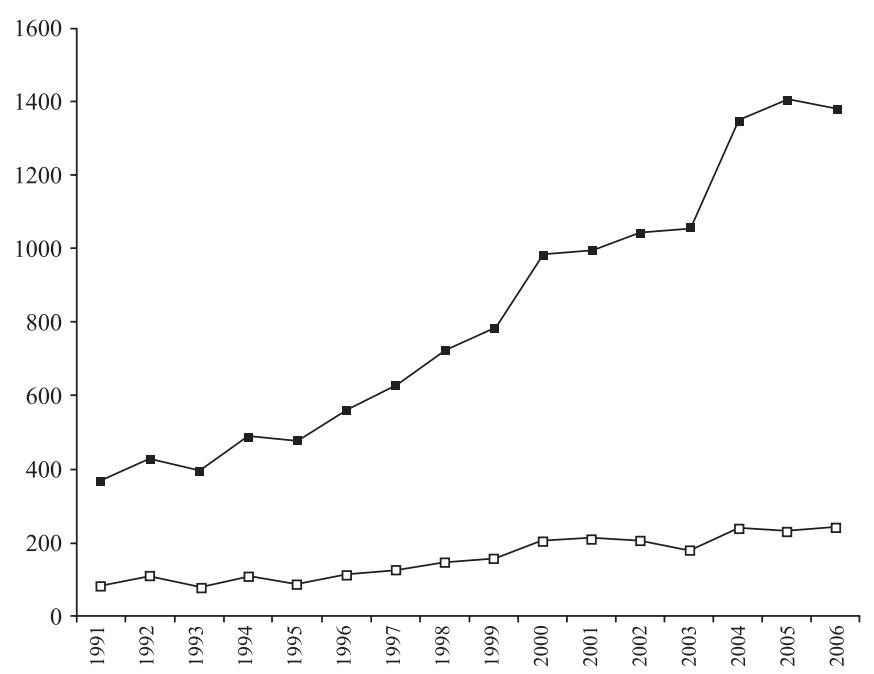

Fig. 2. Number of publications (1991-2006) with biogeograph* in their titles (open squares), and also considering keywords and abstracts (black squares). 


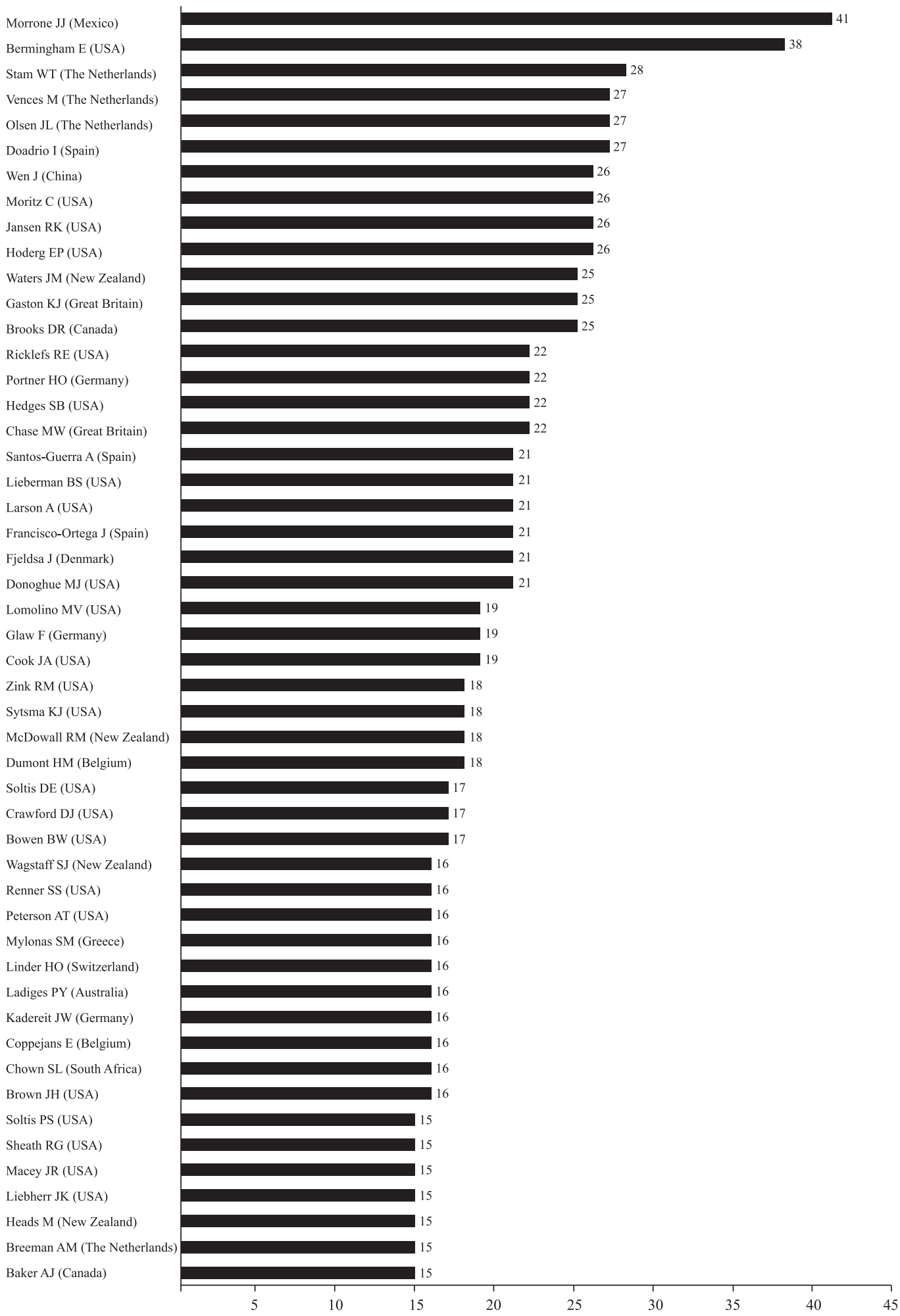

Fig. 3. Most productive authors in biogeography (1991-2006), with indication of the country where they currently work. Only those having 15 or more papers are figured.

France, Germany, Spain, Italy, Mexico, The Netherlands, Japan, China, Brazil, Sweden, Argentina, Belgium and Russia are situated among the countries publishing more papers in biogeography.
Authors. During 1991-2006 there were as many as 17,493 authors contributing to the field. The most productive ones (Fig. 3) work mainly in Anglo-speaking countries, especially the USA, although the first six live in Mexico, The Netherlands and Spain. 


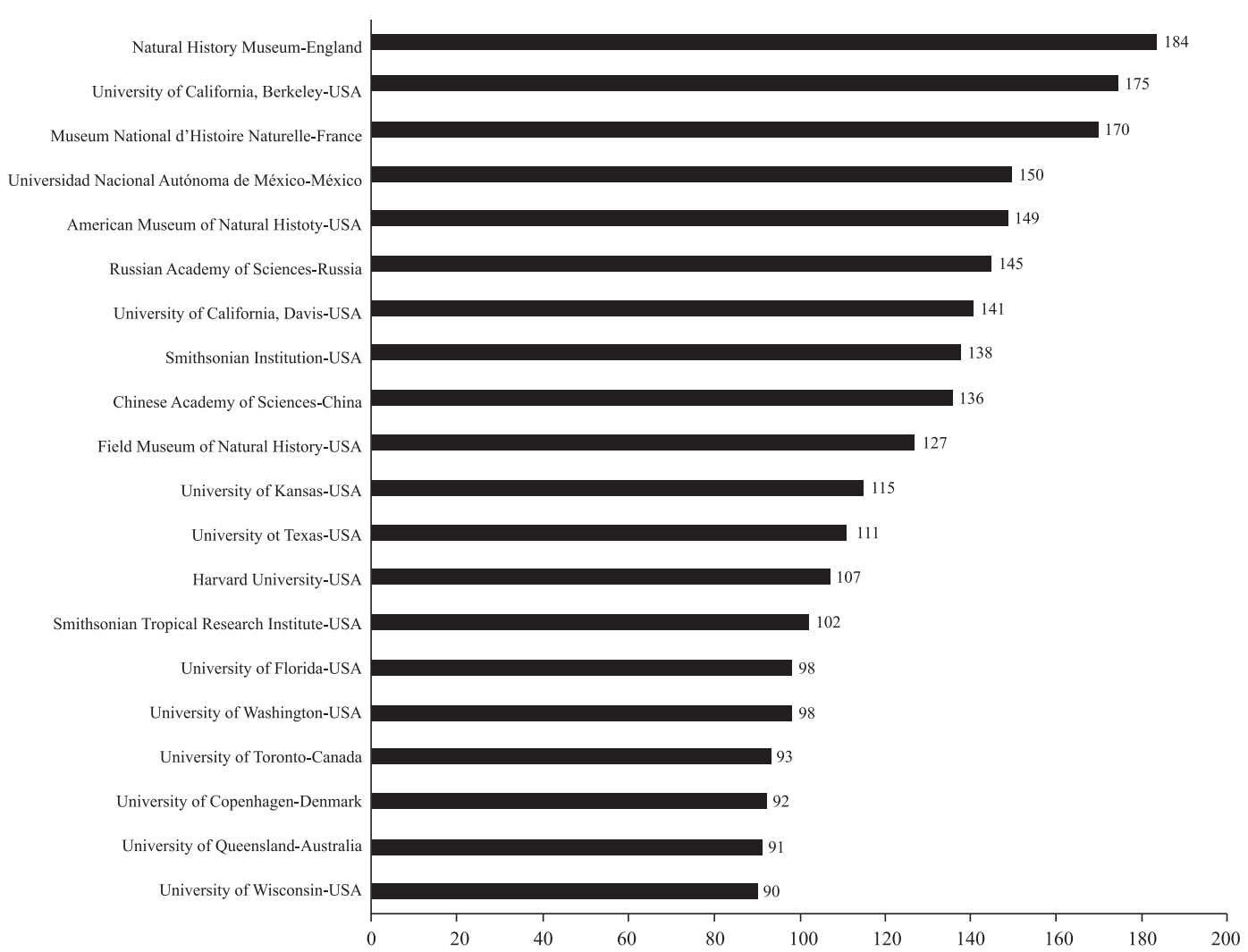

Fig. 4. Institutions with authors involved in biogeographic research (1991-2006). Only those having 90 or more papers are figured

Institutional distribution. During 1991-2006 there were 4098 organizations with authors involved in biogeographic research (Fig. 4). Institutions with higher number of papers are the Natural History Museum (United Kingdom), the University of California, Berkeley (USA), the Museum National d'Histoire Naturelle (France), the Universidad Nacional
Autónoma de México (Mexico), the American Museum of Natural History (USA) and the Russian Academy of Sciences (Russia).

Journals. Research articles in biogeography are spread over a variety of journals (Fig. 5). The core journals, e.g. those

Table I. Country distribution of authorships in biogeography (1991-2006). Only countries whose share is more than $2 \%$ are represented.

\begin{tabular}{llllllllllllllllll}
\hline Countries & 1991 & 1992 & 1993 & 1994 & 1995 & 1996 & 1997 & 1998 & 1999 & 2000 & 2001 & 2002 & 2003 & 2004 & 2005 & 2006 & Total \\
\hline USA & 139 & 119 & 114 & 149 & 181 & 166 & 187 & 186 & 264 & 318 & 355 & 339 & 416 & 437 & 526 & 493 & 4197 \\
United Kingdom & 23 & 24 & 26 & 29 & 45 & 36 & 39 & 54 & 58 & 80 & 68 & 79 & 82 & 89 & 104 & 142 & 922 \\
Australia & 23 & 18 & 26 & 23 & 32 & 40 & 43 & 61 & 47 & 64 & 64 & 86 & 81 & 87 & 109 & 101 & 877 \\
France & 18 & 28 & 28 & 25 & 34 & 32 & 49 & 47 & 43 & 63 & 70 & 68 & 71 & 70 & 81 & 98 & 813 \\
Germany & 8 & 12 & 9 & 13 & 15 & 15 & 25 & 38 & 38 & 54 & 62 & 65 & 84 & 86 & 93 & 122 & 729 \\
Spain & 5 & 18 & 19 & 9 & 20 & 19 & 17 & 38 & 47 & 42 & 46 & 47 & 53 & 72 & 72 & 92 & 609 \\
Canada & 21 & 24 & 29 & 22 & 26 & 33 & 24 & 27 & 38 & 39 & 52 & 40 & 54 & 56 & 70 & 73 & 604 \\
New Zealand & 7 & 5 & 12 & 10 & 9 & 11 & 7 & 15 & 17 & 30 & 35 & 30 & 28 & 33 & 35 & 38 & 309 \\
Italy & 6 & 9 & 7 & 12 & 3 & 13 & 7 & 9 & 13 & 25 & 27 & 23 & 29 & 37 & 29 & 50 & 296 \\
South Africa & 9 & 10 & 10 & 9 & 10 & 7 & 15 & 19 & 16 & 15 & 23 & 26 & 23 & 34 & 37 & 38 & 288 \\
Mexico & 3 & 4 & 2 & 5 & 7 & 5 & 13 & 19 & 11 & 23 & 21 & 21 & 25 & 41 & 40 & 45 & 276 \\
The Netherlands & 10 & 13 & 12 & 13 & 16 & 16 & 16 & 16 & 15 & 10 & 14 & 15 & 30 & 32 & 23 & 31 & 274 \\
Japan & 1 & 2 & 10 & 6 & 7 & 4 & 12 & 14 & 11 & 22 & 23 & 18 & 30 & 38 & 36 & 46 & 273 \\
China & 6 & 3 & 4 & 1 & 8 & 4 & 5 & 12 & 7 & 14 & 17 & 21 & 31 & 34 & 44 & 54 & 259 \\
Brazil & 1 & 4 & 3 & - & 5 & 5 & 11 & 10 & 17 & 16 & 12 & 16 & 22 & 45 & 32 & 62 & 255 \\
Sweden & 6 & 7 & 8 & 5 & 8 & 13 & 9 & 12 & 11 & 12 & 26 & 18 & 22 & 27 & 36 & 31 & 246 \\
Argentina & 8 & 6 & 8 & 8 & 16 & 4 & 13 & 8 & 10 & 22 & 14 & 18 & 21 & 33 & 21 & 39 & 243 \\
Belgium & 3 & 3 & 2 & 5 & 5 & 12 & 10 & 13 & 15 & 15 & 18 & 17 & 23 & 22 & 33 & 30 & 225 \\
Russia & 2 & 6 & 7 & 3 & 9 & 16 & 12 & 9 & 23 & 19 & 18 & 14 & 20 & 17 & 24 & 23 & 212 \\
\hline
\end{tabular}




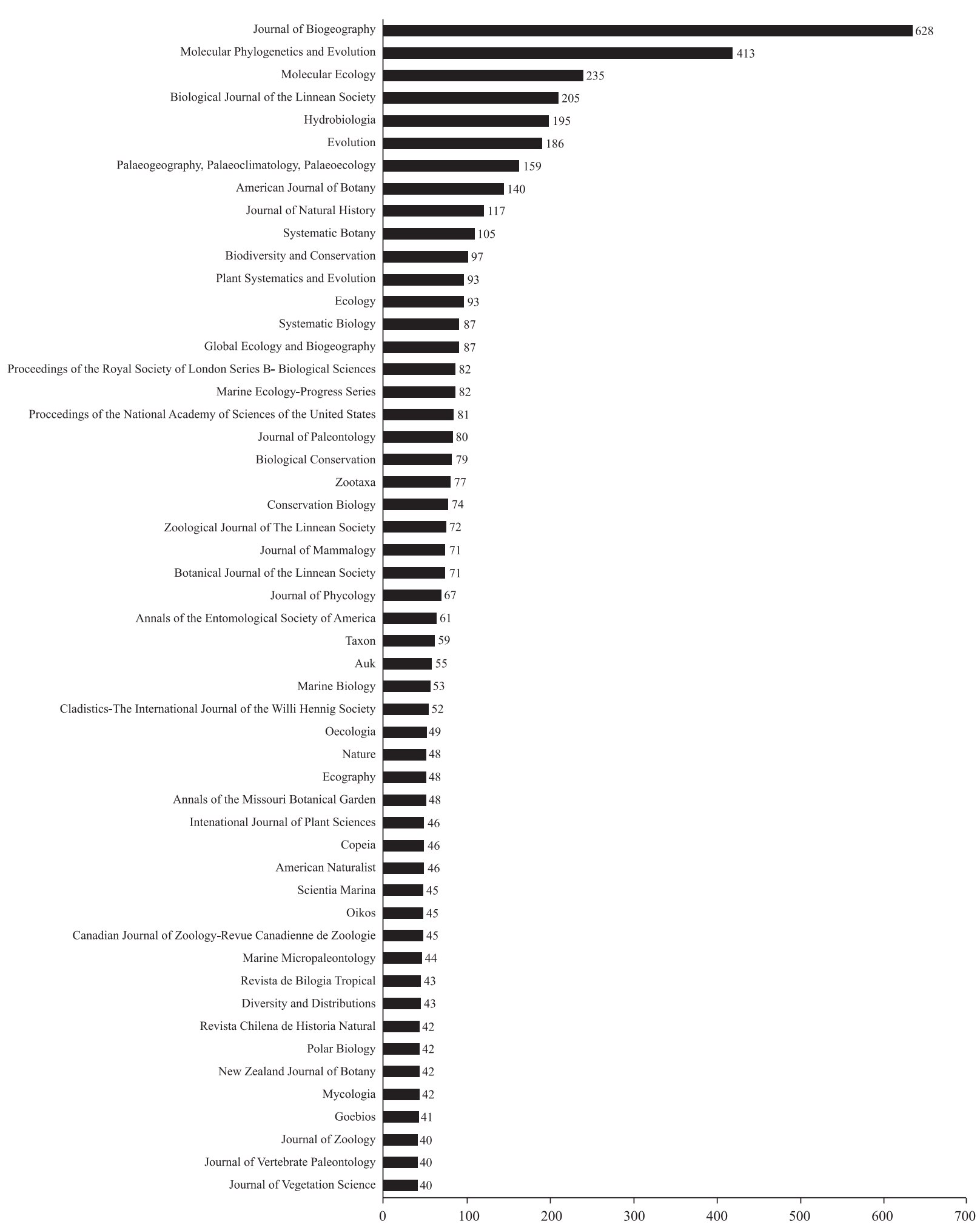

Fig. 5. Journals publishing research on biogeography (1991-2006). Only those having 40 or more papers are figured.

that have published more than 100 papers in the field, are the Journal of Biogeography (628 papers), Molecular Phylogenetics and Evolution (413), Molecular Ecology (235), Biological Journal of the Linnean Society (205), Hydrobiologia (195), Evolution (186), Palaeogeography,
Palaeoclimatology, Palaeoecology (159), American Journal of Botany (140), Journal of Natural History (117), and Systematic Botany (105).

Keywords. We obtained 28,759 keywords, taken from 10,543 


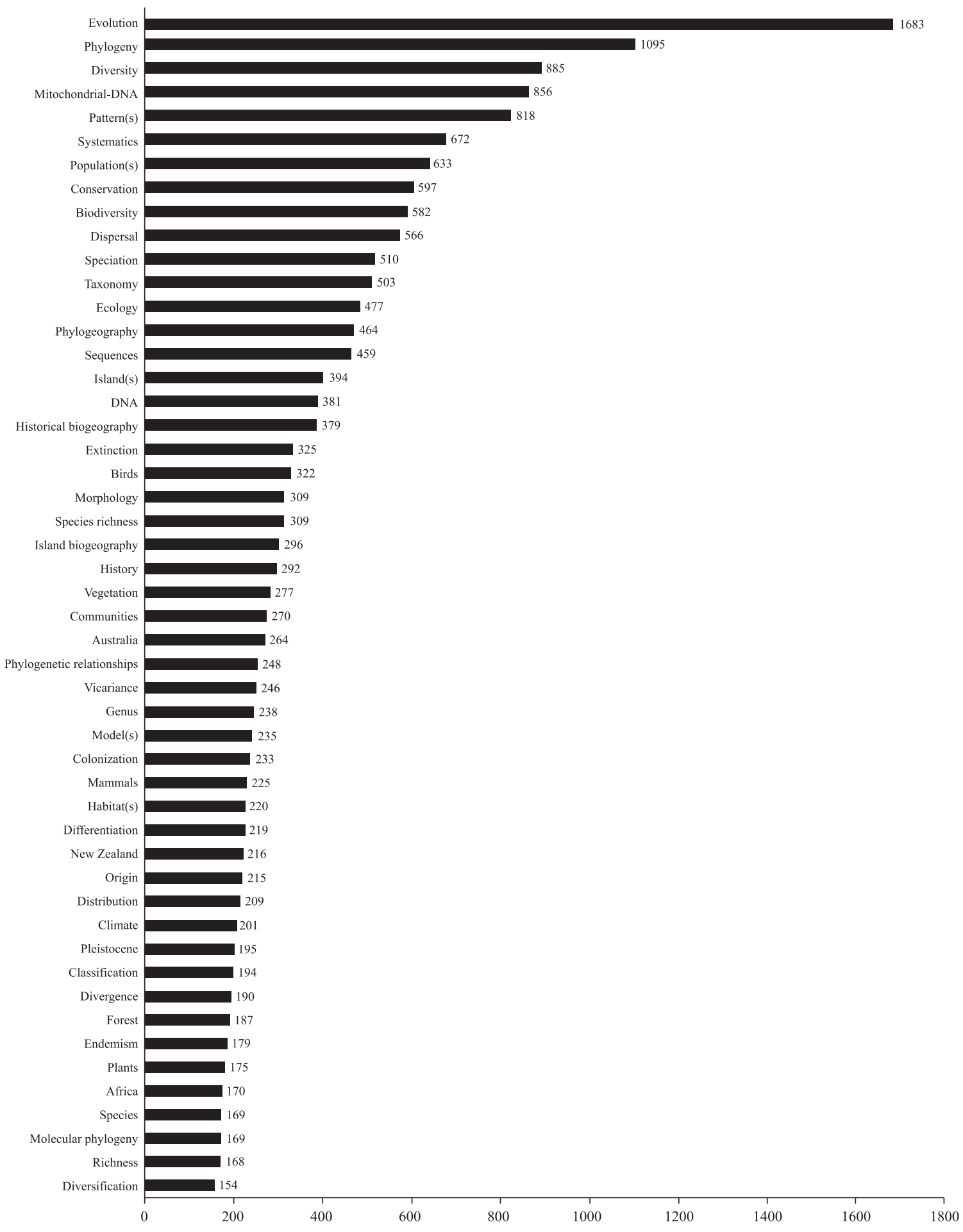

Fig. 6. Most frequent keywords, with indication of the number of times they have appeared in publications (1991-2006).

articles from 1991-2006 (Fig. 6). Those with the highest frequency were: evolution (1683), phylogeny (1095), diversity (885), mitochondrial DNA (856), pattern(s) (818), systematics (672), and population(s) (633). Most frequent taxa included birds (322), mammals (225), and plants (175). Most frequent geographic areas were Australia (264), New Zealand (216), and Africa (170).

\section{DISCUSSION}

The analysis shows that publications on biogeography have increased substantially during the last years, especially since 1998. USA is the major producer, with $39 \%$ of the publications in the period 1991-2006, followed by United 
Kingdom, Australia, France, Germany, Spain, and Canada. Institutions with the highest numbers of publications on biogeography are situated in United Kingdom, USA, France, Mexico and Russia. As noted by Posadas \& Donato (2007), the relevance of Latin American authors and institutions is worth mentioning, given the limited economic resources available to them, when compared with the USA or European countries.

Core journals where biogeographic papers have been published include the Journal of Biogeography, Molecular Phylogenetics and Evolution, Molecular Ecology, Biological Journal of the Linnean Society, Hydrobiologia, Evolution, and Palaeogeography, Palaeoclimatology, Palaeoecology. Analysis of the papers published in these journals, as done by Posadas \& Donato (2007) for the Journal of Biogeography in 2005-2006, may give more specific aspects of the dynamics and evolution of the field.

Keywords are useful bibliometric indicators, that may help establish in which direction a discipline is growing. The most frequently found keywords seem to indicate that biogeography fits well within both evolutionary biology and ecology. Molecular biology and phylogenetics represent important factors that drive the current development of biogeography, which is also evident by the fact that Molecular Phylogenetics and Evolution and Molecular Ecology are among the three core journals.

If papers from other databases which are not covered by the SCI were included, the figures might change significantly. Particularly, a bias toward journals printed in English in SCI may be a handicap for a worldwide analysis, because many papers published in other languages are not taken into consideration. On the other hand, books and book chapters, not covered by SCI, may constitute an additional source of valuable information. Our conclusions are therefore subject to these limitations.

Acknowledgments. We thank Malte Ebach, Ana L. Márquez, Layla Michán, Jesús Olivero, and Raimundo Real for helpful comments on the manuscript.

\section{REFERENCES}

Ferner, R. E. \& J. K. Aronson. 2005. National differences in publishing papers on adverse drug reactions. British Journal of Clinical Pharmacology 59: 108-111.

Garg, K. C. \& P. Pahdi. 2002. Scientometrics of laser research in India during 1970-1984. Scientometrics 55: 215-241.

Posadas, P. \& M. Donato. 2007. Everything you always wanted to know about historical biogeography, but were afraid to ask: A preliminary overview based on papers published in Journal of Biogeography 2005-2006. Biogeografía 2: 26-31.

Riddle, B. R. \& D. J. Hafner. 2004. The past and future roles of phylogeography in historical biogeography. In: Frontiers of biogeography: New directions in the geography of nature (ed. by M. V. Lomolino \& L. R. Heaney), Sinauer Associates Inc., Sunderland, Massachusetts, pp. 93-110.

Thomson ISI Researchsoft. 1998-2003. Endnote version 7.0.0.

Zhu, X.; Q. Wu; Y. Z. Zheng \& X. Ma. 2004. Highly cited papers and the evaluation of a research university: A case study: Peking University 1974-2003. Scientometrics 60: 237-247.

Zorzettto, R.; D. Razzouk; M. T. B. Dubugras; J. Gerolin; N. Schor; J. A. Ghimaraes \& J. J. Mari. 2006. The scientific production in health and biological sciences of the top 20 Brazilian universities. Brazilian Journal of Medical and Biological Research 39 1513-1520. 